Gut, 1972, 13, 285-288

\title{
Effect of oral hypoglycaemic agents on glucose tolerance in pancreatic diabetes
}

\author{
B. I. JOFFE, W. P. U. JACKSON, S. BANK, AND A. I. VINIK \\ From the Department of Medicine, Witwatersrand University Medical School, Johannesburg, the Gastro- \\ intestinal and Endocrine Research Units of Cape Town University Medical School, and the Chemical \\ Pathology Department of Natal University, South Africa
}

SUMMARY The short-term therapeutic effect of oral hypoglycaemic agents has been assessed in 12 patients with symptomatic diabetes secondary to chronic pancreatitis (pancreatic diabetes). In six patients who had moderate to severe carbohydrate intolerance, associated with severe insulinopaenia during arginine infusion, the potent sulphonylurea chlorpropamide produced no change in the fasting blood glucose level after two weeks of treatment. This contrasted with the significant reduction produced in a matched group of maturity-onset primary diabetics. The six patients with milder diabetes, and a greater (although still subnormal) insulin secretory capacity, showed an improvement in oral glucose tolerance during the first hour following glucose administration while on chlorpropamide. When the biguanide phenformin was substituted for chlorpropamide in five of these patients, a statistically insignificant improvement in glucose tolerance was observed during treatment.

Applications of these findings to the practical management of pancreatic diabetes are briefly considered.

Chronic pancreatitis is frequently complicated by diabetes (pancreatic diabetes). Recent studies utilizing immunoassay procedures (Joffe, Bank, Jackson, Keller, O'Reilly, and Vinik, 1968; Anderson Davison, Dick, Hales, and Owens, 1970) have indicated that when carbohydrate intolerance supervenes, insulin reserve is often considerably diminished. However, treatment of the diabetes with exogenous insulin may be complicated by severe hypoglycaemic episodes (Bank, 1966). A study was therefore designed to assess the short-term effect of oral hypoglycaemic agents in pancreatic diabetics with reference to their insulin-secretory status. The results of blood glucose concentrations and glucose tolerance before and after treaiment are reported in this paper.

\section{Patients and Methods}

\section{PATIENTS}

Twelve non-obese patients with proven chronic pancreatic disease were studied. There were 10 men

Received for publication 25 January 1972. and two women, ranging from 30 to 67 years of age. The diagnosis of pancreatitis was confirmed on the basis of a gross abnormality in at least two aspects of the pancreatic function test, namely, a low volume of pancreatic secretion (normal >140 ml) measured 80 minutes after secretin or pancreozymin stimulation; a mean bicarbonate level of $50 \mathrm{~m}$-equiv/litre or less (normal > 65 m-equiv/litre); and a mean amylase value of 4.0 Pimstone units $/ \mathrm{ml}$ or less (normal >5.0 Pimstone units $/ \mathrm{ml}$ ). Furthermore, radiological evidence of pancreatic calcification was observed in 11 of these patients, while steatorrhoea (faecal fat excretion $>5 \mathrm{~g}$ per day) was present in two-thirds of cases. Alcohol was thought to be of aetiological importance in all instances; despite this, clinical, biochemical, and histological evidence of liver disease was absent in all except one case. Six of the 12 patients had had clinical diabetes for longer than a year (maximum duration seven years) and in the remainder symptomatic diabetes was recently discovered. Only one had previously suffered from ketosis. None gave a family history of diabetes, had previously received regular insulin therapy, or was taking drugs known to affect carbohydrate metabolism. 
EXPERIMENTAL DESIGN

After stabilization on a 2000 calorie 'diabetic' diet, patients were arbitrarily divided on the basis of fasting blood sugar determinations into two groups: those with elevated fasting levels, ie, above $120 \mathrm{mg} /$ $100 \mathrm{ml}$, were labelled 'moderate to severe' diabetics and those with normal fasting values designated as 'mild' diabetics. Each group consisted of six patients.

\section{Arginine and chlorpropamide studies}

The insulinogenic effect of arginine, a potent stimulus to beta cell activity (Floyd, Fajans, Conn, Knopf, and Rull, 1966), was estimated in the two groups in an attempt to establish their insulin secretory capacity. For this purpose, $30 \mathrm{~g}$ arginine infusion studies were performed after an overnight fast in four of the severe pancreatic diabetics, all six mild patients, and also in seven non-obese normal male controls. Plasma samples for immunoreactive insulin determinations were obtained fasting, at the completion of the 30-minute infusion period, and half hourly for a further hour. The fasting and peak insulin values recorded during the test in each patient were used for analysis.

In the moderate to severe group, therapy was then instituted with $500 \mathrm{mg}$ of chlorpropamide daily and after two weeks a repeat fasting blood glucose level obtained in each case. For comparison a group of seven recently diagnosed maturity-onset primary diabetics of matched age and severity were similarly investigated. The six mild pancreatic diabetics were subjected to formal $50 \mathrm{~g}$ oral glucose tolerance tests and then treated with chlorpropamide in an average daily dose of $375 \mathrm{mg}$. After a two-week period repeat glucose tolerance tests were performed. In five of these patients chlorpropamide was then withdrawn and a further glucose tolerance test carried out a month later; it was felt that with a biological half-life of about 36 hours, 'carry-over' chlorpropamide activity would be negligible at this stage. Thereafter they were given phenformin (in a dose of $50 \mathrm{mg}$ sustained release capsule twice a day) for a two-week period at the end of which a final glucose tolerance test was done.

All tolerance tests were performed at rest, after an overnight fast; patients who were tested while on oral agents took their usual morning dose one to two hours before the start of the test.

\section{METHODS}

Glucose was determined half-hourly for two hours on capillary whole blood, using a Technicon AutoAnalyzer and the modified ferricyanide method of Hoffman (1937). Plasma insulin during the arginine infusions was measured by radioimmunoassay (Hales and Randle, 1963).

\section{Results}

Table I indicates the insulin secretory capacity of the two pancreatic diabetic subgroups, together with that of normal controls, as evidenced by their fasting and peak plasma immunoreactive insulin responses to intravenous arginine. Although fasting levels were similar, a tendency for insulin reserve to diminish with deteriorating carbohydrate tolerance was apparent. Numbers were too small for statistical evaluation of results.

\begin{tabular}{llrl}
\hline Group & $\begin{array}{l}\text { No. of } \\
\text { Subjects }\end{array}$ & \multicolumn{2}{l}{$\begin{array}{l}\text { Plasma Insulin }(u U / m) \\
\text { after Arginine }\end{array}$} \\
\cline { 2 - 4 } & & Fasting & Peak \\
\hline $\begin{array}{llrl}\text { Moderate to severe pancreatic } \\
\text { diabetics }\end{array}$ & 4 & $9 \pm 1$ & $12 \pm 2$ \\
$\begin{array}{l}\text { Mild pancreatic diabetics } \\
\text { Controls }\end{array}$ & 6 & $9 \pm 2$ & $21 \pm 4$ \\
\hline
\end{tabular}

Table I Fasting and peak plasma insulin responses (mean $\pm S E M$ ) after $30 \mathrm{~g}$ arginine infusions in the severe and mild pancreatic diabetics as well as in seven controls

The effect of chlorpropamide (in a uniform dose of $500 \mathrm{mg}$ daily) on fasting blood glucose levels in the six patients with moderate to severe pancreatic diabetes is shown in Table II. The drug produced no appreciable change in the mean fasting value, compared with the significant fall observed in the group of maturity-onset primary diabetics.

\begin{tabular}{llllll}
\hline $\begin{array}{lllll}\text { Diabetic } \\
\text { Group }\end{array}$ & $\begin{array}{l}\text { No. of } \\
\text { Subjects }\end{array}$ & Age & $\begin{array}{l}\text { Blood } \\
\text { Glucose }(\mathrm{mg} / \\
100 \mathrm{ml})\end{array}$ & Significance \\
\cline { 3 - 6 } & \multicolumn{6}{c|}{$\begin{array}{l}\text { Before } \\
\text { Treatment }\end{array}$} & $\begin{array}{l}\text { After } \\
\text { Treatment }\end{array}$ \\
\hline Pancreatic & 6 & 46 & $237 \pm 25$ & $241 \pm 25$ & NS \\
Primary & 7 & 51 & $187 \pm 17$ & $130 \pm 15$ & $<0.05$ \\
\hline
\end{tabular}

Table II Effect of chlorpropamide on fasting blood glucose levels (mean $\pm S E M$ ) in moderate to severe pancreatic and primary diabetics

Table III summarizes the changes in glucose tolerance induced by chlorpropamide in the six patients with mild pancreatic diabetes. Significant improvement in the mean fasting, 30-, and 60minute glucose values occurred during therapy but later levels showed no significant differences.

Table IV outlines the effect of phenformin on glucose tolerance in five of these mild pancreatic diabetics when it was substituted for chlorpropamide (after the latter had been withdrawn for a month). Except for the fasting level, which showed no 


\begin{tabular}{llllll}
\hline Situation & \multicolumn{4}{l}{$\begin{array}{l}\text { Blood Glucose }(\mathrm{mg} / 100 \mathrm{ml}) \text { after Glucose } \\
\text { Administration }\end{array}$} \\
\cline { 2 - 6 } & Fasting & $30 \mathrm{Min}$ & $60 \mathrm{Min}$ & $90 \mathrm{Min}$ & $120 \mathrm{Min}$ \\
\hline Before therapy & $107 \pm 4$ & $217 \pm 16$ & $273 \pm 10$ & $240 \pm 17$ & $201 \pm 16$ \\
After therapy & $76 \pm 11$ & $155 \pm 19$ & $222 \pm 19$ & $233 \pm 15$ & $207 \pm 10$ \\
Significance & $<0.02$ & $<0.05$ & $<0.05$ & $\mathrm{NS}$ & $\mathrm{NS}$ \\
\hline
\end{tabular}

Table III Effect of chlorpropamide on blood glucose levels (mean $\pm S E M$ ) during oral glucose tolerance tests in six mild pancreatic diabetics

\begin{tabular}{llllll}
\hline Situation & \multicolumn{5}{l}{$\begin{array}{l}\text { Blood Glucose }(\mathrm{mg} / 100 \mathrm{ml}) \text { after Glucose } \\
\text { Administration }\end{array}$} \\
\cline { 2 - 6 } & Fasting & $30 \mathrm{Min}$ & $60 \mathrm{Min}$ & $90 \mathrm{Min}$ & $120 \mathrm{Min}$ \\
\hline Before therapy & $92 \pm 8$ & $188 \pm 14$ & $246 \pm 14$ & $228 \pm 14$ & $172 \pm 23$ \\
After therapy & $91 \pm 13$ & $153 \pm 24$ & $174 \pm 35$ & $158 \pm 31$ & $126 \pm 16$ \\
Significance & NS & NS & NS & NS & NS \\
\hline
\end{tabular}

Table IV Effect of phenformin on blood glucose levels (mean $\pm S E M)$ during oral glucose tolerance tests in five mild pancreatic diabetics

change, all other mean glucose values were reduced on treatment. However, none of these differences reached statistical significance.

\section{Discussion}

Allowing for spontaneous variations in glucose tolerance (Jackson, Vinik, Joffe, Sacks, and Edelstein, 1970) and fluctuations in the underlying disease process, the present findings (confined to a short period) suggest an inability of the potent sulphonylurea chlorpropamide to influence fasting blood glucose values at all in the more severe cases of pancreatic diabetes. This contrasts with its beneficial effect in maturity onset primary diabetes, as indicated both by the present and larger studies (Reaven and Dray, 1967). The improvement in carbohydrate tolerance during the first hour following glucose administration observed in the milder pancreatic diabetics while on therapy is in keeping with their greater (although still subnormal) insulin secretory capacity. Recent evidence suggests that sulphonylureas mainly act by releasing insulin earlier at a higher level and in a more normal pattern in response to physiological stimuli (Prendergast and Forsham, 1970).

The biguanide preparations, whose hypoglycaemic effects are exerted independently of the pancreas (Sterne, 1964), might be expected to offer particular therapeutic advantages in pancreatic diabetes-but the improvement in glucose tolerance seen with phenformin in the milder cases was statistically unimpressive. (For this reason it was not tried in the more severe diabetics.) Furthermore, some recent observations (Hollobaugh, Rao, and Kruger, 1970), indicating a significant effect of phenformin in inhibiting intestinal absorption of glucose (and possibly other nutrients), suggest that its long-term use in chronic pancreatitis, with subclinical maldigestion, may require special care.

With regard to the practical management of pancreatic diabetes, some conclusions may be drawn. Most patients with persistent and symptomatic elevation of fasting blood glucose levels will probably require insulin-albeit cautiously because of possible sensitivity (Bank, 1966; Joffe, Bank, and Marks, 1968). In milder cases with large postprandial elevations of blood glucose sulphonylurea preparations can be expected to produce partial improvement; combination with a biguanide might have a synergistic effect, as is the case in primary diabetes. The desire to achieve strict biochemical control, however, should be balanced by observations that pancreatic diabetics may be less susceptible than primary diabetics to the vascular complications of their diabetes (Siperstein, Unger, and Madison, 1968; Joffe, Novis, Seftel, Krut, and Bank, 1971) although they are not entirely 'immune' (Sevel, Bristow, Bank, Marks, and Jackson, 1971).

We should like to thank Dr I. N. Marks for allowing us to study patients under his care, Mr M. G. Toyer for assisting with the glucose tolerance tests, Mrs R. E. Joffe for secretarial help, and the South African Medical Research Council for financial aid.

\section{References}

Anderson, M. F., Davison, S. H. H., Dick, A. P., Hales, C. N., and Owens, J. (1970). Plasma insulin in pancreatic disease. Gut, 11, 524-531.

Bank, S. (1966). The management of diabetes in the underprivileged, with special reference to pancreatic diabetes. $S$. Afr. med. J., 40, 342-346.

Floyd, J. C., Jr., Fajans, S. S., Conn, J. W., Knopf, R. F., and Rull, J. (1966). Stimulation of insulin secretion by amino acids. $J$. clin. Invest., 45, 1487-1502.

Hales, C. N., and Randle, P. J. (1963). Immunoassay of insulin with insulin-antibody precipitate. Biochem. $J$., 88, 137-146.

Hoffman, W. S. (1937). A rapid photoelectric method for the determination of glucose in blood and urine. J. biol. Chem., 120, 51-55.

Hollobaugh, S. L., Rao, M. B., and Kruger, F. A. (1970). Studies of the site and mechanism of action of phenformin. Diabetes, 19, 45-49.

Jackson, W. P. U., Vinik, A. I., Joffe, B. I., Sacks, A., and Edelstein, I. (1970). Vicissitudes encountered in a diabetes population study. S. Afr. med. J., 44, 1283-1287.

Joffe, B. I., Bank, S., Jackson, W. P. U., Keller, P., O'Reilly, I. G., and Vinik, A. I. (1968). Insulin reserve in patients with chronic pancreatitis. (Letter to the Editor.) Lancet, 2, 890-892.

Joffe, B. I., Bank, S., and Marks, I. N. (1968). Hypoglycaemia in pancreatitis. Lancet, 2, 1038.

Joffe, B. I., Novis, B., Seftel, H. C., Krut, L., and Bank, S. (1971). Ischaemic heart-disease and pancreatic diabetes. (Letter to the Editor.) Lancet, 2, 269.

Prendergast, J. J., and Forsham, P. H. (1970). Compartmental and early phase insulin release after glyburide. (Abstr.). In Proceedings of the 7th Congress of the International Diabetes Federation, Buenos Aires, 1970, p. 159. 
Reaven. G., and Dray, J. (1967). Effect of chlorpropamide on serum glucose and immunoreactive insulin concentrations in patients with maturity-onset diabetes mellitus. Diabetes, 16, 487-492.

Sevel, D., Bristow, J. H., Bank, S., Marks, I., and Jackson, P. (1971). Diabetic retinopathy in chronic pancreatitis. Arch. Ophthal., 86, 245-250.
Siperstein, M. D., Unger, R. H., and Madison, L. L. (1968). Studies of muscle capillary basement membranes in normal subjects, diabetic, and prediabetic patients. J. clin. Invest., 47, 1973-1999.

Sterne, J. (1964). The present state of knowledge on the mode of action of the antidiabetic diguanides. Metabolism 13, 791798. 